khi điều trị bệnh nhân TTPL có ảo thanh thì cần phải quan tâm đến liệu pháp lao động và việc làm. Vì khi có việc làm thì ảo thanh thường mất đi và bệnh nhân dễ đi vào giấc ngủ hơn ${ }^{8}$. Vì vậy, cần kết hợp điều trị hóa dược với các liệu pháp nhận thức hành vi, phục hồi chức năng, tái hòa nhập xã hội, khi điều trị bệnh TTPL.

\section{KẾT LUẦN}

- Không tìm thấy mối liên quan giữa kích động với giới tính, trình độ học vấn và tình trạng nghề nghiệp. Có mối liên quan giữa kích động mức đô̂ năng với nhóm tuổi dưới 31 tuổi; sống ở nông thôn; với tiền sử gây hấn; bỏ điều trị và tình trạng cưỡng ép nhập viện.

- Mức độ kích động không có sự khác biệt có ý nghĩa thống kê giữa nhóm bệnh nhân không có hoang tưởng, ảo giác và nhóm bệnh nhân chỉ có hoang tưởng đơn thuần. Mức độ kích động cao hơn ở nhóm bệnh nhân có kết hợp hoang tưởng, ảo giác so với nhóm bệnh nhân chỉ có hoang tưởng đơn thuần hoặc không có hoang tưởng, ảo giác và khác biệt có ý nghĩa thống kê. Có mối tương quan giữa kích động ở bệnh TTPL với hoang tưởng bị hại và ảo thanh giọng nói.

\section{TÀI LIÊU THAM KHẢO}

1. Nguyễn Văn Tho. Đặc điểm lâm sàng trạng thái kích động tâm thần vận động ở bệnh nhân tâm thần phân liệt. Nghiên cứu y học. 2009;65(6):74-78.

2. Caqueo-Urízar A., Fond G., Urzúa A. et al. Violent behavior and aggression in schizophrenia: Prevalence and risk factors. A multicentric study from three Latin-America countries. Schiophrenia Research. 2016;178(1-3):23-28.

3. Zhou J.S, Zhong B.L, Xiang Y.T, et al. Prevalence of aggression in hospitalized patients with schizophrenia in China: A meta-analysis. AsiaPacific Psychiatry. Mar 2016;8(1):60-69. doi:10.1111/appy.12209

4. Cornaggia CM, Beghi M, Pavone F, Barale F. Aggression in psychiatry wards: a systematic review. Psychiatry research. Aug 30 2011;189(1):10-20.

doi:10.1016/j.psychres.2010.12.024

5. George $\mathbf{C}$, Jacob TR, Kumar AV. Pattern and correlates of agitation in an acute psychiatry inpatient setting in a teaching hospital. Asian Journal of Psychiatry. Feb 2016;19:68-72. doi:10.1016/j.ajp.2015.11.010

6. Cheung $P$, Schweitzer I, Crowley $K$, Tuckwel V. Violence in schizophrenia: role of hallucinations and delusions. Schizophrenia Research. 1997/08/29/ 1997;26(2):181-190. doi:https:// doi.org/10.1016/S0920-9964(97)00049-2

7. Nguyến Kim Viêt. Nghiên cứu tác đônng của ảo thanh ra lệnh đối với cảm xúc - hành vi ở bệnh nhân tâm thần phân liệt. $Y$ học lâm sàng. 2009; 43:48-51.

8. Nguyê̂n Văn Tuấn, Nguyễn Viết Thiêm, Lã Thị Bưởi. Đăc điểm ảo giác trong bênh tâm thân phân liệt. Tạp chí Y học thực hành. 2005;3(505):77-79.

\title{
KẾT QUẢ 6 NĂM ĐIỀU PHốI, BẢO QUẢN, VẬN CHUYỂN TIM GHÉP TAI VIẸT NAM
}

\author{
Phùng Duy Hồng Sơn ${ }^{1,3}$, Trịnh Hồng Sơn ${ }^{1,2,3}$, Nguyễn Hữu Ước ${ }^{1,3}$
}

\section{TÓM TẮT}

Mục tiêu: Báo cáo nhằm tổng kết và chia sẻ kinh nghiệm điều phối, bảo quản, vân chuyển tim người hiến giai đoạn 2015 - 2021. Đối tượng và phương pháp: Báo cáo tổng quan về điều phối ghép tim tại Việt Nam và nghiên cứu mô tả các trường hợp vận chuyển tim có liên quan đên bênh viên Hữu nghi Viêt Đức. Kết quả: Có 16 tim hiến, 01 khối tim phổi được điều phối, bảo quản và vân chuyển. Quãng đường vẩn chuyển trung bình là $304,4 \pm 307,1 \mathrm{~km}$ (2-1730). Vận chuyển bằng hàng không dân dụng là12 ca. Thời gian thiếu máu lạnh là 4,2 \pm 2giờ(0,5-6,25). 100\% ca ghép

${ }^{1}$ Bệnh viện Hữu nghi Việt Đức,

${ }^{2}$ Trung tâm điều phối ghép tạng Quốc gia, ${ }^{3}$ Đai hoc Y Hà Nôi

Chịu trách nhiệm chính: Nguyễn Hữu Ước

Email: uocdhyhn101@yahoo.com.vn

Ngày nhận bài: 12.8.2021

Ngày phản biên khoa hoc: 7.10.2021

Ngày duyệt bài: 13.10.2021 thành công về mặt kỹ thuật. Sau ghép: 1 ca dùng bóng đối xung nôi đông mach chủ, 1 ca tử vong sớm (khối tim-phổi) do biến chứng ngoài tim. Có 1 ca $(6,25 \%)$ tứ vong sau 14 tháng do thải ghép, với thời gian theo dõi trung bình là $31,4 \pm 30,4$ tháng (5-78). Đối với nhóm có liên quan bệnh viên Việt Đức, tim hiến được bảo quản băng dung dịch Custodiol, giữ lạnh ở nhiệt độ $4-8^{\circ} \mathrm{C}$, nhắc lại lần đâu sau 2 giờ và sau đó cứ mỗi giờ môt lần. Kết luân: Khắc phưc khó khăn, tận dụng mọi nguồn lực hiện có, chúng ta đã tổ chức thành công viêc điều phối, bảo quản và vân chuyển tim ghép, với kết quả thu được là khả quan và an toàn.

Tư khóa: Ghép tim, điều phối, vận chuyển, bảo quản, tim hiến.

\section{SUMMARY \\ SIX YEARS'S RESULTS OF DONOR HEART COORDINATION, PRESERVATION, TRANSPORT IN VIETNAM}

Background: The report aims to summarize and share experiences on coordination, preservation and 
transport of donor hearts for the period of 2015 2021. Methods: An overview report on donor heart coordination in Vietnam and a descriptive study of donor heart transport cases that have related to Viet Duc University Hospital. Results: Sixteen donor hearts and one cardiopulmonary block were coordinated, preserved and transported. The average transport distance was $304.4 \pm 307.1 \mathrm{~km}$ (2-1730). Twelve cases were transported by domestic airline. The average duration of cold ischemia is $4.2 \pm 2$ hours (range $0.5-6.25$ ). $100 \%$ of transplants was technically successful. In post-transplant follow up one case was used IABP, one hospital death (cardiopulmonary block) was occurred due to non-cardiac complications. There was one patient $(6.25 \%)$ died after 14 months due to rejection. The average follow-up time was 31.4 \pm 30.4 months (range $5-78$ ). For the group related to Viet Duc Hospital, donor hearts were preserved with Custodiol solution, kept refrigerated at $4-8^{\circ} \mathrm{C}$. The Custodiol preservation was repeated every hour after first two hours. Conclusion: Overcoming difficulties, making use of all available resources, we have successfully organized the coordination, preservation and transportation of donor hearts, with positive and safe results.

Keywords: Heart transplantation, coordination, preservation, transport, donor heart.

\section{I. ĐẠT VẤN ĐỀ}

Ghép tim từ người cho (hiến) tạng chết não là giải pháp điều trị cuối cùng cho nhiêu bệnh suy tim giai đoạn cuối và nhu cầu ghép luôn cao hơn so với số tim được hiến ${ }^{1-3}$. Tuy nhiên, do yêu cầu chă̆t chẽ về các tương thích sinh học người cho người nhận, nên nhiều khi tim hiến không có người nhận tương thích tai cùng môtt cơ sở y tế, nhưng lại có ở 1 vùng khác, thậm chí ở một quốc khác. Điều này đòi hỏi sự ra đời của các cơ quan điều phối ghép tạng của vùng, quốc gia. Tại các nước phát triển như Mỹ, Canada, các nước Châu Âu, Nhât Bản ...; thì hê thống này đã phát triển và hoạt động rất hiêu quả ${ }^{4}$. Tai Viêt Nam, tuy Trung tâm điều phối và ghép tạng Quốc gia (TTĐPGTQG) được chính thức thành lập từ $2013^{4}$. Qua thời gian, vừa làm vừa rút kinh nghiêm, cho tới nay công tác điều phối đã được hệ thống hóa và tổ chức tương hoàn chỉnh đóng góp không nhỏ vào sự thành công của chuyên ngành ghép tạng ở Việt Nam ${ }^{4}$.

Báo cáo nhằm tổng kết và chia sẻ kinh nghiệm điều phối, vận chuyển, kỹ thuật bảo quản tim trên đường vận chuyển, từ trường hợp đâuu tiên năm 2015 cho tới nay và nhìn lại y văn.

\section{II. ĐỐI TƯỢNG VÀ PHƯƠNG PHÁP NGHIÊN CỨU}

Báo cáo tổng quan về điều phối, vận chuyển tim hiến dựa trên kinh nghiệm 17 trường hợp tại Việt Nam, đối chiếu với y văn thế giới và mô tả qui trình bảo vệ tim, tổ chức vận chuyển của bệnh viện (BV) Hữu nghị Việt Đức.

Đạo đức nghiên cứu: Nghiên cứu nhằm nâng cao chất lượng ghép tim tại Việt Nam, được sư cho phép của BV Hữu nghi Việt Đức và TTंĐPGTQG. Các thông tin được bảo mật và chỉ phục vụ cho nghiên cứu.

\section{KẾT QUẢ NGHIÊN CỨU}

Trong giai đoạn từ tháng 1 năm 2015 đến tháng 10 năm 2021, có 22 ca điều phối tạng ghép - trong đó có 16 quả tim và 1 khối tim phổi. Chi tiết các ca điều phối tim được mô tả trong bảng 1 .

Bảng 1. Thời gian, nơi lây, nơi nhận tạng, vận chuyển - bảo quản tim người hiến

\begin{tabular}{|c|c|c|c|c|c|c|}
\hline \multirow{2}{*}{$\pi$} & \multirow{2}{*}{ Thời gian } & \multirow{2}{*}{ BV lấy } & \multirow{2}{*}{ BV ghép } & \multicolumn{2}{|c|}{ Bảo quản - vận chuyến } & \multirow{2}{*}{$\begin{array}{l}\text { Phương tiện vận } \\
\text { chuyển chính }\end{array}$} \\
\hline & & & & Việt Đức** & Khác & \\
\hline 1. & $20 / 7 / 2015$ & Chợ Rây & Huế & - & Huế & Hàng không dân dụng \\
\hline 2. & $04 / 09 / 2015$ & Chợ Rây & Việt Đức & + & - & Hàng không dân dụng \\
\hline 3. & $26 / 04 / 2016$ & Chợ Rây & Việt Đức & + & - & Hàng không dân dụng \\
\hline 4. & $12 / 12 / 2017$ & 108 & Viềt Đức & + & - & Xe cứu thương \\
\hline 5. & $26 / 2 / 2018$ & 108 & Chợ Rây & + & - & Hàng không dân dụng \\
\hline 6. & $5 / 4 / 2018$ & Đồng Nai & Chợ Rây & + & Chợ Rây & Xe cứu thương \\
\hline 7. & $16 / 5 / 2018$ & Việt Đức & Huế & - & Huế & Hàng không dân dụng \\
\hline 8. & $14 / 6 / 2018$ & Việt Đức & Huế & + & Huế & Hàng không dân dụng \\
\hline 9. & $26 / 1 / 2019$ & Việt Đức & Huế & - & Huế & Hàng không dân dụng \\
\hline 10. & $29 / 6 / 2019$ & Việt Đức & Chợ Rầy & + & Chợ Rầy & Hàng không dân dụng \\
\hline 11. & $15 / 8 / 2019$ & 108 & Huế & - & Huế & Hàng không dân dụng \\
\hline 12. & $16 / 08 / 2019$ & Chợ Rầy & Việt Đức & + & - & Hàng không dân dụng \\
\hline 13. & $31 / 08 / 2019$ & 103 & Huế & - & Huế & Hàng không dân dụng \\
\hline 14. & $13 / 05 / 2020$ & Việt Đức & Chợ Rây & + & Chợ Rây & Hàng không dân dụng \\
\hline 15. & $16 / 09 / 2020$ & Bv 108 & Việt Đức & + & - & Xe cứu thương \\
\hline 16. & $04 / 5 / 2021$ & Bà Rịa & Chợ Rây & + & Chợ Rây & Xe cứu thương \\
\hline 17. & $17 / 5 / 2021$ & Bà Rịa & Chợ Rây & + & Chợ Rây & Xe cứu thương \\
\hline
\end{tabular}


*BV Việt Đức thực hiện toàn bộ hay tham gia thực hiện việc lấy, bảo quản, vận chuyển; hoặc do bênh viện khác thực hiện theo qui trình của BV Việt Đức

Ngoài 4 BV được phép thực hiện kỹ thuật ghép tim (Việt Đức, 103, Huế, Chợ Rẫy), còn có 3 BV khác tham gia vào quá trình lấy đa tạng từ người cho chết não (108, Đồng Nai, Bà Rịa). Phương tiện vận chuyển bằng xe cứu thương chỉ mới dành cho khoảng cách vận chuyển chừng $100 \mathrm{~km}$. Vận chuyển hàng không được thực hiện tại các sân bay gần địa điểm lấy và ghép tim nhất (Nội Bài, Huế, Đà Nẵng, Tân Sơn Nhất).
Vận chuyển tạng giữa các BV và sân bay được thực hiện bằng xe cứu thương với sự trợ giúp của lực lượng cảnh sát giao thông. Thời gian lấy tim ra khỏi lồng ngực người hiến khoảng 2 giờ trước giờ bay - thời gian đủ để di chuyển ra sân bay và hoàn tất các thủ tục hàng không. Liên hệ trước với bộ phận quản lý cảng hàng không để cho phép xe cứu thương chở tim vào tân bến đậu máy bay và ưu tiên cho kíp vận chuyển tạng ngồi ở vị trí thuận lợi cho kỹ thuật bảo vệ tạng bổ sung trên đường vận chuyển. Ngay sau khi máy bay hạ cánh, hiệu lệnh mở ngực bệnh nhân nhận tim cũ̃ng được đưa ra.

Bảng 2. Thông tin tương đôî về quãng đường vận chuyển và thời gian thiếu máu

\begin{tabular}{|c|c|c|c|c|c|}
\hline TT & BV lấy & BV ghép & $\begin{array}{l}\text { Khoảng cách } \\
\text { (km) }\end{array}$ & $\begin{array}{l}\text { Thời gian vân } \\
\text { chuyển (giớ) }\end{array}$ & $\begin{array}{l}\text { Tống thời gian } \\
\text { thiếu máu(giờ) }\end{array}$ \\
\hline 1. & Chợ Rây & Huế & 950 & $2,4^{*}$ & Không có thông tin \\
\hline 2. & Chợ Rây & Việt Đức & 1.730 & 6 & 7,5 \\
\hline 3. & Chợ Rây & Việt Đức & 1.730 & 5,8 & 7,3 \\
\hline 4. & 108 & Việt Đức & 2 & 0,5 & 2 \\
\hline 5. & 108 & Chợ Rây & 1.730 & 4,75 & 6,25 \\
\hline 6. & Đồng Nai & Chợ Rây & 35 & 1 & 2,5 \\
\hline 7. & Việt Đức & Huế & 754 & 5 & 6,5 \\
\hline 8. & Viềt Đức & Huế & 857 & 6,25 & 7,25 \\
\hline 9. & Việt Đức & Huế & 857 & 6,25 & 7,25 \\
\hline 10. & Việt Đức & Chợ Rây & 1.730 & 4,75 & 6,25 \\
\hline 11. & 108 & Hंuế & 754 & 5 & 6,5 \\
\hline 12. & Chợ Rây & Việt Đức & 1.730 & 4,75 & 6,25 \\
\hline 13. & 103 & Huế & 754 & 5 & 6,5 \\
\hline 14. & Việt Đức & Chợ Rây & 1.730 & 4,75 & 6,25 \\
\hline 15. & Bv 108 & Viềt Đức & 2 & 0,5 & 2 \\
\hline 16. & Bà Rịa & Chợ Rây & 100 & 2,5 & 4 \\
\hline 17. & Bà Rịa & Chợ Rây & 100 & 2,5 & 4 \\
\hline & & Trung bình & $304,4 \pm 307,1$ & $4,2 \pm 2,0$ & $5,6 \pm 1,9$ \\
\hline
\end{tabular}

*Thời gian vân chuyển đơn thuần - Không xác định được tổng thời gian thiếu máu lạnh.

Như vậy, quãng đường vận chuyển xa nhất là 1730 km giữa Hà Nội và Thành phố Hồ Chí Minh, thời gian thiếu máu lạnh dài nhất (thời gian vận chuyển) là 6,25 giờ, và tổng thời gian thiếu máu dài nhất là 7,5 giờ đối với ghép tim đơn thuần (được tính bằng thời gian thiếu máu lạnh $+1,5$ giờ - thời gian kỹ thuật ghép tim trung bình của BV Việt Đức).

Kết quả phẫu thuật ghép tim: 100\% thành công về kỹ thuật; ca ghép khối tim-phổi tử vong sớm vào ngày thứ 5 sau mổ do biến chứng chảy máu trên nền ECMO; 1 ca suy tim ghép cấp (ca số 3) phải sử dunng bóng đối xung nội động mạch chủ (IABP). Thời gian theo dõi trung bình là 31,4 $\pm 30,4$ tháng (5-78), với 1 ca tử vong sau 14 tháng do thải ghép (ca số 5).

Quy trình bảo quản tim hiến trên đường vận chuyển hàng không của BV Việt Đức

Phẫu tích và chuẩn bị lấy tim + các tạng khác (gan, thận) như quy trình thường qui trước giờ bay khoảng 3 tiếng.

Bảo vệ cơ tim bằng dung dịch Custodiol như mổ tim hở qua kim gốc động mạch chủ.

Đảm bảo cắt rời tim khỏi cơ thể người hiến trước giờ bay khoảng 2 tiếng

Điểm khác biệt: (Hình 1).

$\checkmark$ Giữ nguyên kim bơm dịch bảo vệ cơ tim và kẹp (clamp) động mạch chủ.

$\checkmark$ Nối kim liệt tim với dây chuyền dịch vô trùng loại ren xoắn (tránh tuột), và đâu còn lại được đưa ra ngoài thùng đựng tạng nối với túi đựng dung dịch Custodiol lạnh (ngâm trong nước đá).

$\checkmark$ Chay thử dung dịch bảo vê cơ tim và kiểm tra hiệu quả (gốc động mạch chủ căng phồng).

$\checkmark$ Cho tim vào túi đựng dung dịch Custodiol lạnh $200 \mathrm{ml}$, (chọn túi có thể tích lớn tùy theo 
thời gian dự kiến vận chuyển). Làm xẹp túi và buộc miệng túi bằng dây chun vô khuẩn (cổ găng tay). Sau khi buộc, kiểm tra dịch bảo vệ tim có thể chảy qua dây truyền không, tránh buộc quá chặt.

$\checkmark$ Cho túi chứa tim vào túi thứ 2 có chứa đá lạnh xay nhỏ, buộc lại như trên, sau cho vào túi thứ 3, làm tương tự, kiểm tra dịch bảo vệ tim có chảy qua được không.

$\checkmark$ Bơm Custodiol bảo vệ cơ tim lần 2 sau lần đầu khoảng 2 giờ (thời gian bảo vệ tối đa của thuốc), rồi nhắc lại sau đó mỗi giờ, với liều nhắc lại như mổ tim hở thường qui - trên đường vận chuyển (Hình 1).

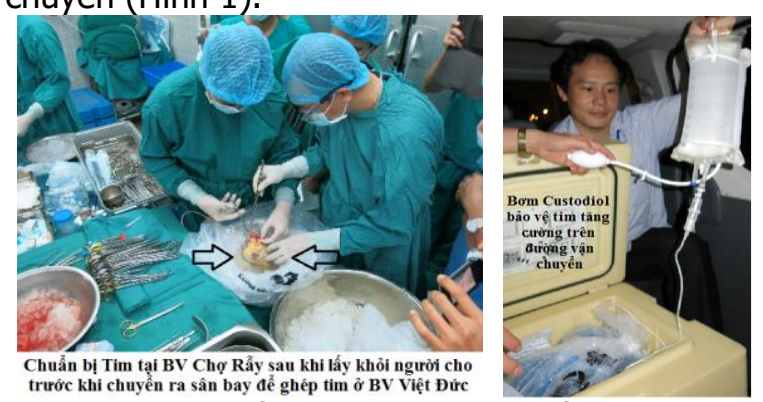

Hình 1. Chuẩn bị và vận chuyển tím hiến

- Đặt tim vào thùng bảo quản theo qui trình vận chuyển tim. Thùng bảo quản có thể đơn giản như thùng giữ nhiệt hoặc thùng điều khiển nhiệt độ $4-8^{\circ} \mathrm{C}$ hiện đại (Hình 2).

- Vận chuyển ngay tim đến xe cứu thương và đi thẳng ra sân bay, có cảnh sát dẫn đường (nếu ở giờ cao điểm), làm thủ tục ưu tiên và lên máy bay ở vị trí thuận lợi cho các biện pháp bảo vệ cơ tim bổ sung (thường ở gần khoang nhân viên tổ bay).

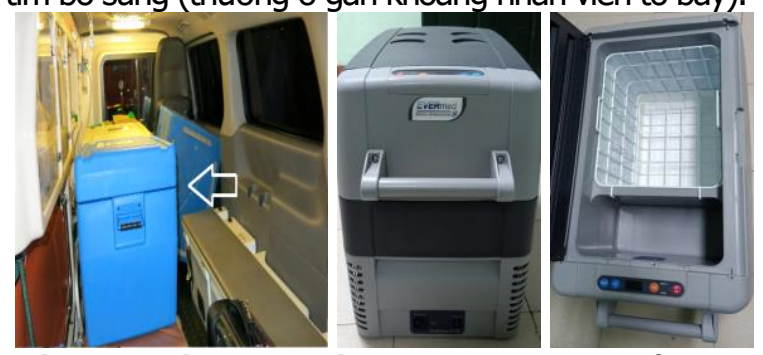

Hình 2. Các loại thùng đựng tim đã sử dụng tại BV Việt Đức

\section{BÀN LUÂ̂N}

Theo thống kê tại Mỹ, số lượng người chờ ghép tim tăng 42,6\% từ 2008 đên 2019 (từ 5304 lên 7562 người). Mặc dù số người hiến chết não tăng 63,6\% từ 2008 đến 2019, nhưng riêng cho năm 2019 chỉ là 3635 người, ít hơn 3927 ca so với nhu câu cùng thời gian². Sự mất cân đối này đòi hỏi phải có cách sử dụng nguồn tạng hiến tối ưu, và đây là một thực tế thúc đẩy sự hình thành các cơ quan điều phối ghép tạng tại các quốc gia trên thế giới - thậm chí cả một khối (như Châu Âu). Mạng lưới phân phối tạng của Mỹ (UNOS) thành lập năm 1984, hệ thống ghép tạng Nhật Bản (JOT) thành lập năm $1997^{4}$. Cũng theo quy luật phát triển ngành ghép tạng từ cuối những năm 2000 tại Việt Nam, TTĐPGTQG được thành lập vào năm $2013^{4}$. Dưới sự chỉ đạo năng động và linh hoạt của Trung tẩm, trong giai đoạn 2015-2021, đã thực hiện được 22 trường hợp điều phối ghép tạng giữa các vùng - miền (bảng $1)$, trong đó có 16 ca điều phối tim.

Giai đoạn đầu trước năm 2018, ghép tim chỉ thực hiện tại Hà Nội và Huế, sau đó có thêm bệnh viện Chợ Rẫy thành phố Hồ Chí Minh. Với số lượng ca ghép ít, danh sách chờ ghép không nhiều nên không phải lúc nào có người hiến cũng có người nhận phù hợp tại các miền. Thực tế này thúc đẩy sự hình thành phương thức lấy - vận chuyển tạng mang tính tự phát giữa các bệnh viện lớn, như trường hợp lấy khối tim phổi từ thành phố Hồ Chí Minh về Huế vào ngày 20/7/2015 mà không có sự tham gia của TTĐPGTQG ${ }^{4}$ (bảng 1,2), tuy nhiên sự phối hợp rất tốt nên thời gian vận chuyển chỉ mất 2,4 giờ 5 . Ca điều phối đầu tiên bắt đầu có sự tham gia của Trung tâm là vào ngày $04 / 09 / 2015$ - vận chuyển tim và gan lấy từ BV Chợ Rấy ra ghép tại BV Việt Đức ${ }^{4}$ (bảng 1), tuy nhiên phương thức tổ chức còn rời rạc, phụ thuộc nhiều vào năng lực cá nhân của các thành viên đoàn công tác. Càng về sau này, công tác tổ chức càng tốt hơn, và cho đến năm 2020 thì đã hoàn thiện hầu hết các qui trình vận chuyển tạng với vai trò chủ đạo của TTĐPGTQG. Trong 17 ca vận chuyển có tim, quãng đường trung bình là $304,4 \pm 307,2 \mathrm{~km}$, xa nhất là $1730 \mathrm{~km}$ và gần nhất là $2 \mathrm{~km}$, thời gian thiếu máu lạnh và tổng thời gian thiếu máu trung bình lần lượt là $4,2 \pm 2$ giờ $(0,5-6,25)$ và $5,6 \pm 1,9$ giờ $(2-7,75)$ (bảng 2). Đây là sự sáng tạo và cố gắng vượt bậc của các thây thuốc Việt Nam, vì tại các nước phát triển, từ hàng chục năm nay, đã có nhiều trung tâm có thể ghép tim được phân bố hợp lý về địa lý tại mỗi quốc gia. Họ có các Trung tâm điều phối và mạng lưới phân phối tạng hoàn chỉnh, các bệnh nhân có nhu cầu ghép được đưa vào danh sách chờ ghép và chủ động điều hành các phương tiện chuyên dụng cho vận chuyển tạng. Thông báo của Atik và cộng sự̂́ tại viện tim mạch liên bang Brazil, trong khoảng thời gian từ tháng 09/2006 $10 / 2012$ có 41 ca ghép tim, trong đó 11 ca lấy tim ở xa, trung bình $792 \pm 397 \mathrm{~km}$, thời gian thiếu máu trung bình 212 min \pm 32 (khoảng 3,5 
$\pm 0,5$ giờ). Kết quả hai nhóm lấy xa và lấy gần là như nhau trong thời gian theo dõi từ 1 đến 12 tháng. Gaffey AC và cộng sự hồi cứu $25.996 \mathrm{ca}$ ghép tim từ tháng $1 / 2000$ đến tháng 12/2013 trên mạng điều phối ghép tạng Mỹ (UNOS) đã kết luận có thể lựa chọn tim hiến phù hợp từ những người hiến tặng ở khoảng cách xa hởn để tăng khả năng cung cấp tạng, lấy tim hiến từ xa không trực tiếp làm tăng tỷ lệ biến chứng và tử vong sau ghép tim.

Bảo quản tim người hiến là vấn đề quan trọng nhất khi vận chuyển tạng đi xa. Các nghiên cứu cơ bản cho thây cần bảo quản bằng dung dịch chuyên dụng và giữ lạnh ở nhiệt độ $4-8^{\circ} \mathrm{C}^{8}$. Ngày nay tại các nước phát triển, bên cạnh phương pháp bảo quản bằng dung dịch hóa chất, ngừng tim và hạ nhiệt độ, đã phát triển phương pháp bảo quản tim đập (ex-vivo perfusion) ${ }^{9}$. Bảo quản tim đập (Hình 3 ) được cho là có nhiều ưu điểm như: thời gian bảo quản dài hơn, sinh lý, có thể điều trị các khiếm khuyết của tim hiến, chống thương tổn do tái tưới máu gây nên, giảm phản ứng miễn dịch, loại bỏ được các chất thải quá trình trao đổi chất, có thể đánh giá được chức năng tim ghép, cung cấp được oxi và thức ăn cho tim hiến thường xuyên ${ }^{9}$. Do chi phí của phương pháp này còn cao, chưa có sản phẩm tại Việt Nam nên chúng tôi chưa có cơ hội áp dụng. BV Việt Đức đã sử dụng phương pháp truyền thống, bảo quản bằng Custodiol và nhiệt độ từ $4-8^{\circ} \mathrm{C}$, tuy nhiên đã sáng tạo trong việc thiết kê hệ thống bảo vệ nhắc lại tim sau mỗi $1-2$ giờ. Phương pháp này được cho là hiệu quả bảo vệ tốt hơn so với chỉ bảo vệ một lần và bảo quản lạnh ${ }^{8}$.

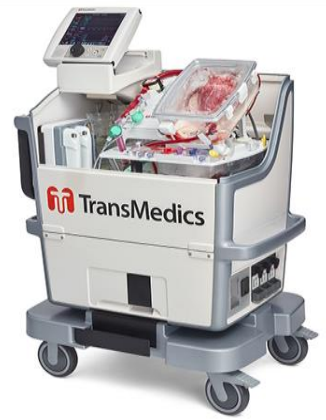

\section{Hình 3. Hê thống OCS Heart-TransMedics bảo quản tim đập nhiệt độ thường (Nguồn Internet)}

Kết quả sau ghép đều thành công về kỹ thuật, ca tử vong sớm (ghép khối tim phổi) không phải do các yếu tố liên quan đến nhiễm trùng hoặc suy tạng do vận chuyển tạng. Trường hợp tử vong muộn sau 14 tháng vì thải ghép do người bệnh không tuân thủ nghiêm qui trình điều trị tại 1 cơ sở chưa có nhiều kinh nghiệm trong chăm sóc bệnh nhân sau ghép tim (bảng 3). Trường hợp suy tim cấp sau mổ cần dùng bóng đối xung nội động mạch chủ do có thời gian thiếu máu kéo dài vì không thuận lợi trên đường vận chuyển hàng không (dài hơn 1 giờ so với dự kiến). Các trường hợp khác đều diễn biến thuận lợi như khi lấy - ghép tim tại chỗ. Thời gian theo dõi sau ghép trung bình là $31,4 \pm 30,4$ tháng (5-78) (bảng 3) với tỷ lệ sống sót khá cao $15 / 16$ ca $(93,8 \%)$. Nghiên cứu của trung tâm điêu phối ghép tạng Mỹ (UNOS) ${ }^{2}$ năm 2019 cho thây tỉ lệ sống sau ghép tim giai đoạn 2011-2013 sau $1,3,5$ năm lần lượt là $90.3 \%, 84.7 \%$ và 79.6\%. Thống kê thứ 37 năm 2020 của Cơ quan đăng ký cấy ghép nội tạng lồng ngực quốc tế công bố tỉ lệ tử vong sau ghép tim 1 và 5 năm lần lượt là $89,9 \%$ và $85 \%$. Như vậy kết quả của chúng tôi tương tự kết quả chung trên thế giới về thời gian sống sau ghép tim.

\section{KẾT LUÂ̂N}

Điều phối, bảo quản và vận chuyển tim lấy từ người cho đa tạng chết não tại Việt Nam bước đầu là khả thi, an toàn và hiêu quả. Kết quả thu được tương đương các nghiền cứu trên thế giới và có thể khuyến cáo cho ứng dụng trong thực hành lâm sàng nhằm tăng tỉ lệ bệnh nhân suy tim giai đoạn cuối được ghép tim.

\section{TÀI LIẸU THAM KHẢO}

1. Khush KK, Cherikh WS, Chambers DC, et al. The International Thoracic Organ Transplant Registry of the International Society for Heart and Lung Transplantation: Thirty-sixth adult heart transplantation report - 2019; focus theme: Donor and recipient size match. J Heart Lung Transplant. 2019;38(10):1056-1066. doi: 10.1016/j.healung.2019.08.004

2. Colvin $\mathbf{M}$, Smith JM, Ahn $\mathbf{Y}$, et al. OPTN/SRTR 2019 Annual Data Report: Heart. American Journal of Transplantation. 2021;21(S2):356-440. doi:10.1111/ajt.16492

3. Khush KK, Potena L, Cherikh WS, et al. The International Thoracic Organ Transplant Registry of the International Society for Heart and Lung Transplantation: 37th adult heart transplantation report-2020; focus on deceased donor characteristics. The Journal of Heart and Lung Transplantation. 2020;39(10):1003-1015. doi: 10.1016/j.healun.2020.07.010

4. Trịnh Hồng Sơn, Nguyễn Hoàng Phúc, Nguyễn Tiên Thành và Cs."Ghi nhận điều phối ghép tạng tại Việt Nam giai đoạn 01/01/2015 31/07/2018", Tạp chí $Y$ học thực hành, số 11 (1119) 2019, tr.102 - 111, 2019.

5. Bùi Đức Phú. Nghiên cứu ghép khối tim phổi trên bệnh nhân được cây thiết bi hố trợ thất trái trong giai đoạn chờ ghép. Đề tài nhánh mã số KC.10.26/11-15, thuộc đề tài KHCN cấp Nhà nước 
- Mã số KC.10/11-15, Nghiêm thu năm 2016.

6. Atik FA, Couto CF, Tirado FP, et al. Addition of long-distance heart procurement promotes changes in heart transplant waiting list status. Rev Bras Cir Cardiovasc. 2014;29(3):344-349. doi:10.5935/1678-9741.20140046

7. Gaffey AC, Chen CW, Chung JJ, et al. Extended distance cardiac allograft can successfully be utilized without impacting longterm survival. The Journal of Heart and Lung Transplantation. 2017;36(9):968-972. doi: 10.1016/j.healun.2017.04.002

8. Charniot J-C, Bonnefont-Rousselot D,
Albertini J-P, et al. Oxidative Stress Implication After Prolonged Storage Donor Heart with Blood Versus Crystalloid Cardioplegia and Reperfusion Versus Static Storage. Journal of Surgical Research. 2010;160(2):308-314. doi: 10.1016/j.jss.2009.03.023

9. Caenegem OV, Beauloye $C$, Bertrand $L$, et al. Hypothermic continuous machine perfusion enables preservation of energy charge and functional recovery of heart grafts in an ex vivo model of donation following circulatory death. Thoracic Surgery.:6.

\section{ĐÁNH GIÁ KẾT QUẢ ĐIỀU TRI UNG THƯ Cổ TỬ CUNG GIAI ĐOAN FIGO IB1-IIA1 BẰNG PHƯƠNG PHÁP PHẪU THUÂTT TẠI BỆNH VIỆN K}

\section{TÓM TẮT}

Nghiên cứu của chúng tôi đánh giá kết quả điều trị của nhóm bệnh nhân ung thư cổ tử cung giai đoan FIGO IB1-IIA1 được phẫu thuật triệt căn ngay từ đầu tại bênh viên $K$. Đối tượng và phương pháp nghiền cứu: Chúng tôi tiến hành nghiên cứu hồi cứu trên 158 bênh nhân ung thư cổ tử cung giai đoan FIGO IB1-IIA1, được phẫu thuật cắt tử cung triệt cằn ngay từ đầu tại bệnh viện $K$ từ tháng $1 / 2016$ đến 1/2019. Các chỉ tiêu nghiển cứu bao gồm một số đăc điểm lâm sàng, cận lâm sàng và kết quả điều trị. Kết quả: Tuổi trung bình: $50 \pm 10,4$ tuổi. Ra máu âm đạo sau quan hệ tình dục là triệu trứng thường găp nhất (70,3\%). Carcinoma tế bào vảy là thể giải phẩu bệnh phỗ biến nhất $(77,2 \%)$. Tỷ lệ di căn hạch chậu sau phẫu thuât là $18,4 \%$. Tỷ lể bểnh nhân điều tri bổ trơ sau phẫu thuât là $45,6 \%$. Tỷ lệ sống thêm toàn bộ 3 năm, 5 năm lần lượt là: $94,8 \%$ và $88,8 \%$. Tỷ lệ sổng thêm không bệnh 3 năm, 5 năm lần lượt là: $87,2 \%$ và $82,5 \%$. Biến chứng cấp tính sau phấu thuật hay gặp nhất là bí tiểu $(12,7 \%)$. Kết luận: Phẫu thuật triệt căn chỉ định cho giai đoan ung thư cổ tử cung giai đoạn FIGO IB1-IIA1 có kết quả sống thêm tốt, an toàn và các biến chứng trong giới hạn chấp nhận được.

Tư khóa: Ung thư cổ tử cung, cắt tử cung triệt căn, sống thêm.

\section{SUMMARY \\ RESULTS OF SURGERY FOR CERVICAL CANCER FIGO IB1-IIA1 AT VIETNAM NATIONAL CANCER HOSPITAL}

Subject: Our study evaluated the outcomes of cervical cancer patients with FIGO stage IB1-IIA1 who underwent radical surgery at the time of diagnosis at

\section{*Bênh viên $K$}

Chịu trách nhiệm chính: Nguyễn Trọng Diệp

Email: drtrongdiep@gmail.com

Ngày nhận bài: 3.8.2021

Ngày phản biên khoa họ: 4.10 .2021

Ngày duyệt bài: 12.10.2021
Vietnam National Cancer Hospital. Method: We conducted a retrospective study on 158 cervical cancer patients with FIGO stage IB1-IIA1, who received radical hysterectomy from January 2016 to January 2019. Patients were assessed for clinical features and treatment outcome. Results: Mean age: $50 \pm 10,4$ years old. Vaginal bleeding was the most common symptom (70.3\%). The most common histopathology was squamous cell carcinoma $(77.2 \%)$. The rate of pelvic lymph node metastasis was $18.4 \%$. The portion of patients received postoperation adjuvant treatment was $45.6 \%$. The rate of overall survival at 3 years, 5 years was $94.8 \% ; 88.8 \%$, respectively. The percent of disease-free survival at 3 years, 5 years was $87.2 \%$; $82.5 \%$, respectively. The most common acute complication after surgery was dysfuntion bladder $(12,7 \%)$. Conclusion: Radical hysterectomy indicated for cervical cancer FIGO IB1-IIA1 has good survival outcomes, safety and acceptable complications.

Key words: Cervical cancer, radical hysterectomy, survival.

\section{I. ĐẶT VẤN ĐỀ}

Ung thư cổ tử cung là bệnh lý ác tính thường gặp, phổ biến đứng hàng thứ hai trong ung thư phụ khoa, thứ tư trong tổng số ung thư ở nữ giớ [1]. Về điêuu trị, phẫu thuật và xạ trị được coi là 2 vũ khí chính có thể điều trị triệt căn, vai trò của hóa chất và điều trị đích là hạn chế. Giai đoạn FIGO IB-IIA là giai đoan u khu trú tai chỗ, tai vùng, có thể điều trị bằng phẫu thuật triệt căn khởi đâu, hay xạ trị tiền phẫu sau đó phẫu thuật, hay xạ trị triệt căn, với tỷ lệ sống thêm tương đương nhau, chỉ khác nhau về các biến chứng [2]. Ưu điểm của phẫu thuật triệt căn là: bảo tôn được chức năng buồng trứng ở phụ nữ trẻ, cho phép đánh giá chi tiết và chính xác mức độ xâm lấn, tình trạng di căn hạch, một số lượng bệnh nhân không cân xạ trị sau mồ có thể tránh các biến chứng do xạ trị. 